\title{
PETER ZUBKO*
}

\section{Tangenty latinsko-byzantského spolužitia pod Karpatmi ako príležitost' pre revitalizáciu hodnôt ${ }^{1}$}

ZUBKO, P.: Tangents of Latin-Byzantine coexistence under the Carpathians as an opportunity for the revitalization of values. Slavica Slovaca, 56, 2021, No 3, pp. 403-408 (Bratislava).

The Latin Church and the Byzantine Church in the area below the Carpathians live side by side for several centuries. This neighborhood has its own historical development, it is divided into several periods. The most important milestone was the establishment of the Greek Catholic Church after the conclusion of the Uzhhorod Union in 1646. As elsewhere in the world, under the Carpathians, various tensions arose in mutual relations. They primarily caused problems that ultimately proved to be beneficial to both parties. The interest in the other and the presentation of one's own values contributed to the spiritual and cultural exchange. Apparent competition has forced each community to deepen its own identity and historical memory. In key historical situations, there was interconnection and action against the external enemies of the church. The common tangents and intersections of the interests of the Latin and Western Churches under the Carpathians have ultimately always been mutually beneficial. This article points out this added value.

Latin-Byzantine relations, the Greek Catholic Church, spiritual heritage of Slovakia, historical memory, theology of history.

Západní a východní krest’ania pod Karpatmi žijú vedl'a seba po stáročia. Za ten čas sa vytvorilo spolužitie, ktoré bolo prospešné pre obidve strany, stalo sa súčasne výmenou hodnôt, názorov a duchovného dedičstva, bolo i hmotným obohatením. Tento priestor a jeho obyvatelia neboli izolovaní a ani vzájomné tangenty nemali výslovne lokálny kontext a význam. Patria do mozaiky vel'kého svetového príbehu relácií medzi latinským (západným) a byzantským (východným) svetom a ich kultúrami. Aj ked' sa niektoré vzt’ahy interpretujú ako napäté, paradoxne vždy posunuli kvalitu života, duchovnosti a kultúrnosti dopredu.

Prví krest'ania mali vel'kú toleranciu pre odlišnosti. Pestrost' pohl'adov na tú istú záležitost' nachádzame už v novozákonných biblických textoch. Odlišné alebo rozličné pohl'ady neboli zámienkou rozdelenia, pretože dôležitá bola vzájomná jednota. ${ }^{2}$ Treba však dodat', že krest’ania sa odlišovali od spoločenstva, z ktorého vyšli (prví krest’ania boli odlišovaní od okolia, boli nazývaní židovskou sektou), od pohanov (vo viacerých martyrológiach je neuctievanie pohanských božstiev označené ako „,bezbožnost““ a bolo dôvodom na ortiel' smrti pre prvých mučeníkov), od tradícií (Vel'ká noc sa zásadne slávila v čase odlišnom od židovského kalendára). Tieto odlišovania upevňovali osobitú krest’anskú identitu. Napriek tomu bolo krest’anské spoločenstvo vo svojom vnútri pestré.

\footnotetext{
* Prof. PhDr. ThDr. Peter Zubko, PhD., Slavistický ústav Jána Stanislava SAV, Dúbravská cesta 9, 84104 Bratislava. ${ }^{1}$ Štúdia v podobe referátu odznela na medzinárodnej vedeckej konferencii s názvom Obraz krízy v jazyku a kultúre. Kríza ako príležitost' pre revitalizáciu hodnotového systému spoločnosti. Vznikla v rámci riešenia projektu APVV-18-0032 "Mytologické predstavy o svete v naratívnych prameňoch na Slovensku v systéme slovanských jazykových a kultúrnych vzt’ahov" a výskumov realizovaných v rámci projektového programu Open Mobility (č. Mob-Open-20-08) v spolupráci Slavistického ústavu Jána Stanislava SAV a Ústavu bulharského jazyka prof. L. Andrejčina BAV na tému „Duchovné hodnoty a tradičná kultúra / Spiritual values and traditional culture“.

${ }^{2}$ Porov. napr. Skutky apoštolov 15,1-35 a List Galat'anom 2,1-10. Ide o dva pohl'ady na apoštolský snem v Jeruzaleme (okolo roku 50), petrovskú a pavlovskú verziu jednej udalosti.
} 
Krest'ania neboli uniformnou masou, už v staroveku sa prirodzene sformovali okruhy dvoch vel'kých cirkevných spoločenstiev, ktoré vznikli v odlišných geografických pomeroch. Neboli izolované, pretože cirkulácia osôb, hmotných i duchovných dobier, ale i mocenské vplyvy prispievali k záujmu o toho druhého. Odlišnosti medzi latinským/rímskym Západom a gréckym/ byzantským Východom sú všeobecne známe, ${ }^{3}$ zvyčajne spôsobili väčšie i menej významné napätia, a to nielen vo svojej dobe, ale vd'aka pamät'ovému efektu sa umelo, ba i zámerne zdôrazňovali aj neskôr. Tieto napätia sa odvíjali od závažnosti problému, ale tiež od osobností, ktoré sa zapojili do riešenia. Hoci by sa mohli mnohé javit' ako negatívne, väčšina pozitívne posunula dobu vpred, prispela k vzájomnému poznaniu a upevneniu jednoty v odlišnostiach alebo obohatila toho druhého o vlastné duchovné bohatstvo. ${ }^{4}$ Primárny charakter problémov bol teologický alebo náboženský, obidve strany radi zdôrazňovali vlastnú pravovernost' (ortodoxiu) a nepravovernost' (bludárskost', schizmatickost', sektárskost') toho druhého v definovaní teologických názorov, náboženských právd a ich uplatňovania v praxi a dodržiavaní cirkevnej disciplíny.

Iné, napríklad kultúrne problémy, boli často interpretované ako teologické. Sakralizácia každodenného života bola prospešná do chvíle, kým sa nezmenila na militantný fundamentalizmus bez vnútornej slobody. Tieto odlišnosti možno rozdelit' na liturgické, zvykové a teologické, pričom niektoré sa prelínajú a dopĺn̆ajú. K najznámejším liturgickým odlišnostiam patrí rítus/obrad a nan̆ sa viažuce liturgické predpisy a zvyklosti, predovšetkým kalendár (juliánsky alebo gregoriánsky), dátum Vel'kej noci, odlišné liturgické sviatky, pôstna disciplína (pôstne dni a zakázané jedlá), eucharistická matéria (kvasený alebo nekvasený chlieb). K zvykovým odlišnostiam patrí napr. (ne)nosenie brady, celibát. Medzi najznámejšie teologické odlišnosti patrí otázka pápežského primátu, Filioque, istý čas k tomu patrili aj názory a prax mariánskeho kultu a kultu ikon/ obrazov, napokon aj náuka o očistci. Čast' odlišností má kultúrny kontext, odlišnosti vznikli v pastoračných akcentoch a prístupoch (vysluhovanie iniciačných sviatostí, duchovné vedenie, riešenie morálnych problémov, spirituálne priority). Problémy, ktoré spôsobili skutočné kontroverzie a rozdelenie, mali politickú a mocenskú povahu, ktorá bola spojená so sebavedomými ambíciami pôvodcov.

$\mathrm{K}$ tangentom, dotykom, stretom medzi Východom a Západom dochádzalo pravidelne z jednej i druhej strany. V prvom tisícročí krest’anstva išlo o rozličné napätia, ktoré boli zámienkou na odsudzovanie, vzd'al'ovanie, obviňovanie. Vyvrcholili v roku 1054 v strete medzi Humbertom a Cerulariom a vzájomnej exkomunikácii. Tento dátum je dodnes symbolom rozdelenia. Následne v druhom tisícročí prebehli viaceré dialógy, viac či menej úspešné. V prvom tisícročí sa týkajú všetkých nábožensko-spoločenských oblastí, v druhom tisícročí sa týkali dominantne teologických otázok a cirkevnej disciplíny. Práve tieto spoločné záujmy prinavrátenia cirkevnej jednoty boli prospešné pre rozvoj dogmatickej teológie. Vd’aka tomu došlo k definovaniu siedmich sviatostí, očistca, trojičnej náuky, ekleziológie, kánonu biblických kníh, ale i chápania primátu. Naposledy boli tieto náuky definované na 17. ekumenickom koncile vo Florencii: úniová bula s Grékmi Laetentur caeli (6. 7. 1439), úniová bula s Arménmi Exultate Deo (22. 11. 1439), úniová bula s Koptmi a Etiópčanmi Cantate Domino (4. 2. 1442), úniová bula so Sýrčanmi Multa et admirabilia (30.9. 1444), úniová bula s cyperskými Chalcedónmi a Maronitmi Benedictus

\footnotetext{
${ }^{3}$ Porov. Chadwick, H.: Historia rozłamu Kościoła Wschodniego i Zachodniego od czasów apostolskich do Soboru florenckiego. Kraków: Wydawnictwo WAM, 2009; Špirko, J.: Cirkevné dejiny s osobitným zretel’om na vývin cirkevných dejín Slovenska. I. - II. Martin: Neografia, 1943.

${ }^{4}$ Napríklad výmena sviatkov: Západ prevzal sviatok Zjavenia Pána a Východ sviatok Narodenia Pána. Ďalej prevzatie mariánskeho kultu Západom.
} 
sit Deus (7. 8. 1445). ${ }^{5} \mathrm{Z}$ toho vyplynula i d’alšia prax, rímska cirkev uznala pravoslávnych svätých, ktorí zomreli do prijatia týchto úniových búl, okrem svätcov v hodnosti biskupov.

V novovekých cirkevných dejinách strednej Európy sa spomínajú dve významné únie, ktoré prežili svoj vznik i prvotné krízy a ich dôsledky sú dodnes evidentné, majú dedičov vo viacerých krajinách. Prvou bola Brestská únia z roku 1596 a druhou Užhorodská únia z roku 1646. Neexistuje medzi nimi priamy kauzálny vzt’ah, ale možno identifikovat' viaceré súvisiace kultúrno-spoločenské okolnosti, ktoré sú podobné. Niektoré javy z pol’ského prostredia inšpirovali uhorské prostredie. Vzt’ahy a tangenty katolícko-pravoslávneho, resp. latinsko-byzantského susedstva majú dve odlišné a samostatné etapy: do uzavretia únie a po uzavretí únie. V prvej fáze možno registrovat' silnú afinitu Východu $\mathrm{k}$ Západu, v druhej fáze došlo k periodickým kritickým udalostiam. K tým sa východná strana sporadicky vracala, nanovo ich interpretovala podl'a potrieb konkrétnej doby, čím sa snažila posilnit' vlastnú identitu, ked' sa ocitla, alebo sa cítila byt' v kríze či v ohrození. Latinská cirkev rozhodujúcu rolu zohrala najmä v pripomínaní a udržiavaní povedomia o únii, pretože ňou vedela zdôvodnit' vznik novej ekleziologickej entity. Podl'a výpovedí kanonickej vizitácie jágerského biskupa Františka Barkóciho v polovici 18. storočia úniu ako takú vo všeobecnosti východné prostredie pod Karpatmi ignorovalo a pokúšalo sa o vlastnú nezávislost'. Ignorovanie stavu únie viedlo latinské k intenzívnejšiemu záujmu o uniatov. Snahy uniatov o vonkajšie zrovnoprávnenie s latinskou cirkvou vyvolávali na uniatskej strane reciprocitu nasmerovanú na duchovné (spirituálne, dogmatické i kultúrne) vyrovnanie sa latinskému prostrediu. Byzantské prostredie bolo vždy možné identifikovat' nábožensky podl'a obradu a liturgickej disciplíny. Väčšinové latinské prostredie ich pomenúvalo náboženskými termínmi: Rutheni (v náboženskom význame rusnáci, nie etnickom Rusíni), schizmatici (ortodoxní, pravoslávni), disuniati (nezjednotení alebo tí, ktorí opustili úniu, alebo v menšinovej pozícii brojili proti únii). Podnes sa o tom vedú terminologické dišputy, ktoré pozitívne vplývajú na identitu samej východnej cirkvi.

Uniati neboli jazykovo jednoliate spoločenstvo, pretože hovorili viacerými jazykmi (slovensky, rusínsky, mad’arsky, rumunsky). Počas valašskej kolonizácie dominovali ortodoxní Valasi nad Rusínmi a podl'a výpovedí prameňov možno predpokladat', že nešlo o etnografické termíny, ale o etnické pomenovania; kým Rusíni si dodnes zachovali vlastnú identitu aj vd'aka osobitnému jazyku (zjavne odlišnému od väčšinového), Valasi sa v prvej-druhej generácii po usídlení polatinčili (stali sa rímskokatolíkmi, resp. latinskými katolíkmi). V tomto kontexte by bolo možné interpretovat' pôvod niektorých zobrazení stredovekých fresiek (Narodenie Krista v latinských kostoloch v obciach Kostol'any pod Tríbečom, Ludrová, Vizsoly), ktoré majú typický východný výzor. Na druhej strane to dokladá užšiu spätost' a jednotu medzi východnou a západnou kultúrou pred reformáciou, čoho príkladom je aj vyšívaná Panna Mária (Bohorodička) ako orantka na korunovačnom plášti uhorských král'ov. ${ }^{6}$

Bez poznania, pochopenia a porovnania kl'účových udalostí unionizmu v Pol'sku nie je možné dobre poznat' unionizmus pod Karpatmi. Užhorodská únia a niektoré d’alšie udalosti boli stotožňované s vývinom v Pol’sku, konkrétne s Brestskou úniou, alebo sa dávali do priameho vzt’ahu so Zamoščskou synodou. Komparácia potvrdzuje pol'skú úniu ako morálny vzor, ale Užhorodská únia mala úplne odlišný vývin i priebeh a s pol'skou úniou je nekompatibilná; uhorským výsledkom nebola klasická cirkevná únia, ale personálna únia, ktorá vznikla po zložení

\footnotetext{
${ }^{5}$ Baron, A. - Pietras, H. (eds.): Dokumenty Soborów Powszechnych III (1414-1445). Kraków: Wydawnictwo WAM Księża Jezuici, 2003, s. 458, 492, 570, 628, 636.

${ }^{6}$ Tóth, E.: A magyar szent korona és a koronázási jelvények. Budapest: Országház könyvkiadó, 2018, s. $284-285$.
} 
prísahy vernosti jágerskému biskupovi v roku 1646, viackrát bola obnovená (1649 a 1652), naposledy v roku 1726/7 v súvislosti s dianím v Pol'sku. Vplyv Zamoščskej synody nie je preukázatel'ný v prameňoch, vníma sa len sprostredkovane. Presný dátum vzniku únie dlho nebol pre uniatov dôležitý, osciloval medzi rokom 1646 a 1649, ale všeobecnejšia mienka sa klonila $\mathrm{k}$ roku $1649,{ }^{7}$ ba dlho o ňom vôbec nepochybovala, ${ }^{8}$ hoci niektorí historici sa zastávali aj roku 1652. ${ }^{9}$ Až výskum spojený s hl'adaním vlastných koreňov a identity pomohol ustálit’ rok jej vzniku na 1646, no väčšiu úlohu tu zohralo filozoficko-teologické rozhodnutie hl'adajúce Boha vo vlastných dejinách; tento princíp sa nazýva locus theologicus.

Od vzniku Užhorodskej únie do kanonického erigovania Mukačevského gréckokatolíckeho biskupstva (1646-1771) boli riadnymi miestnymi ordinármi jágerskí biskupi latinského obradu. Pre veriacich východného rítu bol vymenovaný obradový vikár, ktorým bol konsekrovaný biskup, vybraný spomedzi uniatskych presbyterov. Biskupi východného rítu tu existovali už pred úniou, hoci neexistujú priame a jednoznačné dôkazy o riadne organizovanej eparchii. Funkcia obradového vikára nebola latinská svojvôl'a, ale rešpektovanie kanonického práva a riadne začlenenie východných veriacich do štruktúr katolíckej cirkvi; tento inštitút ustanovil Štvrtý lateránsky koncil (1215), bola známa pri prísahe vernosti uniatskych presbyterov (1646) a rovnako i v 18. storočí. Zriadenie gréckokatolíckeho biskupstva bolo vo výlučnej kompetencii pápeža. Neochota o podporenie takého riešenia nespočívala v predsudkoch jágerských biskupov k východnému prostrediu; rovnaká neochota existovala aj k dismembrácii vlastného latinského Jágerského biskupstva na nové diecézy v rokoch 1746-1804, čo je takmer 60 rokov. Jágerskí biskupi, osobitne biskup Barkóci, chránili východný obrad ${ }^{10}$ pred latinizáciou. Tá nastúpila až v 19. storočí a iniciatíva vyšla z vnútra Mukačevského gréckokatolíckeho biskupstva a do vel'kej miery súvisela s mad’arizáciou, ktorá sa intenzívne prejavila po rakúsko-mad’arskom vyrovnaní za biskupa Štefana Pankoviča (1820-1874, mukačevský biskup od roku 1867). ${ }^{11}$ To sa zrejme nepáčilo časti gréckokatolíckeho kléru, čo sa prejavilo napr. v Lučkajových názoroch na spoločnú byzantsko-latinskú minulost', čo už bola apologetická reinterpretácia udalostí. V skutočnosti perióda existencie obradového vikariátu východné prostredie disciplinarizovala a otvorila cestu kvalitnému latinskému vzdelaniu a kultúre, čím sa sformovala generácia kňazov, ktorí svoje vzdelanie zúročili v práci pre vybudovanie novozriadeného Mukačevského gréckokatolíckeho biskupstva; toto obdobie sa nazýva „zlatým“ vekom biskupstva.

Kultúrna komparácia ukazuje, že je badat’ zaostávanie východného prostredia za západným, ale tiež vidno hl'adanie inšpirácií v západnom prostredí. Zdanlivé napätia medzi západným a východným krest'anstvom v Karpatoch boli v skutočnosti tvorivým demiurgom pre kultúrny, myš-

\footnotetext{
${ }^{7}$ Táto nejasnost' začiatku únie existovala ešte v roku 1950 i 1960, porov. Lacko, M.: Gréckokatolíkom, s. $43,52$.

${ }^{8}$ Porov. Sirmaj, A.: Historické, topografické a politické poznatky stolice Zemplínskej. Michalovce: Zemplínska spoločnost', 2004, s. 63.

${ }^{9}$ Marianov, I.: Aby všichni jedno byli. Výklad unijní otázky a sbírka modliteb za sjednocení církví. Olomouc: Apoštolát sv. Cyrila a Metoděje, 1939, s. 23.

${ }^{10}$ Obdobný fenomén ochrany východného dedičstva pred nekritickým napodobňovaním latinského prostredia v rovnakom období riešili aj pol'skí biskupi latinského obradu. Porov. Vilinskij, V. S.: Unionizmus. Trnava: Spolok sv. Vojtecha, 1932, s. 80-81.

${ }^{11}$ Pankovičovo krédo znelo: „Žijeme pod nadvládou Mad’arov a musíme sa stat’ Mad'armi.“ Pozri Pop, I.: Malé dejiny Rusínov, s. 55; Pop, I.: Podkarpatská Rus, s. 184-185. O politickom a jazykovom vývine, výskumoch a súvisiacich reflexiách v druhej polovici 19. storočia pozri Švorc, P.: Krajinská hranica medzi Slovenskom a Podkarpatskou Rusou v medzivojnovom období (1919-1939). Prešov: Universum, 2013, s. 11-62; Švorc, P.: Zakliata krajina (Podkarpatská Rus 1918-1946). Prešov: Universum, 1996, s. 14-37; Švorc, P.: Zakletá zem. Podkarpatská Rus 1918-1946. Praha: Nakladatelství Lidové noviny, 2007, s. 33-56.
} 
lienkový i duchovný život ${ }^{12}$ a rast východnej cirkvi v Uhorsku. V stredoveku východní krest’ania vyhl'adávali latinské pútnické miesta (Košice, Spišská Kapitula) a konvertovali na rímsky katolicizmus, počas reformácie prejavovali isté sympatie s kalvinizmom, v 18. storočí prebiehalo kultúrne vyrovnávanie, v 19. storočí zas napodobňovanie latinskej teológie, umenia (ikony sa podobali latinským obrazom, stavali sa tzv. tereziánske chrámy), uhorského vlastenectva (eufemistické pomenovanie mad'arského nacionalizmu), v 20. storočí dominovalo hladanie etnických koreňov zdôrazňovaním rusínskej, ukrajinskej alebo slovenskej autochtónnosti, zdôrazňovalo sa znášanie spoločného údelu proticirkevnej politiky štátu, v 21. storočí sa hl'adajú duchovné korene. ${ }^{13}$ Slovenskí gréckokatolíci sa prihlásili k cyrilo-metodskej tradícii, ktorá bola ešte na prelome 19. a 20. storočia vnímaná skôr ako latinské dedičstvo, hoci vo svete sa k nemu hlásili gréckokatolíci v niekol'kých krajinách. Cyrilo-metodská idea viedla ku kreatívnemu zrodeniu myšlienky o priamej kontinuite s vel'komoravskou cirkvou; ide však o kultúrny jav nazývaný interkulturácia a má teologické, pastoračné ciele, nejde o historickú interpretáciu.

V roku 1950 bola gréckokatolícka cirkev „zrušená“ po tzv. Prešovskom sobore v rámci tzv. Akcie P. Následne zohrala latinská cirkev klúčcvú úlohu univerzálneho katolíckeho spoločenstva, ked' prijala a starala sa o gréckokatolíkov, ktorí odmietli stat' sa pravoslávnymi. Išlo o tých veriacich, ktorí svoju vieru pokladali za katolícku, nešlo im „len“ o obrad, ktorý v tomto kontexte bol atribútom kultúry. Klúčové osobnosti gréckokatolíckej inteligencie boli nespravodlivo väznené, alebo museli odíst' do vyhnanstva do českého pohraničia v rámci Akcie 100, alebo sa stiahli z verejného života zo zdravotných a emeritných dôvodov. Táto absurdná doba trvala do obnovenia gréckokatolíckej cirkvi v roku 1968, ale všetky krivdy už nebolo možné napravit'.

Po Druhom vatikánskom koncile sa v rímskokatolíckej cirkvi prehíbil záujem o krestanský Východ na najvyššej úrovni. Vznikla Kongregácia pre východné cirkvi, ktorá primárne zastrešuje všetky východné cirkevné spoločenstvá. Klúčcovou úlohou bola kodifikácia Kódexu kánonov východných cirkví, ktorý bol promulgovaný v roku 1990.

Na Slovensku po roku 1989 prešla gréckokatolícka cirkev novou etapou vývoja. Patrí k nej vonkajšia obnova, konštituovanie a zvel’adenie cirkevnej organizácie, tiež hladanie vlastných koreňov. Nateraz sa javí ako hladanie vonkajších znakov (oblečenie podl'a pravoslávnych vzorov, stavba nových chrámov, mal'ovanie ikon podl'a gréckych vzorov - na odlíšenie od predchádzajúceho vývoja), budovanie vlastnej autority na nedávnej martýrskej minulosti (blahorečenie mučeníkov z obdobia komunistickej neslobody). Ako pridaná hodnota sa objavuje záujem o východnú patrológiu, hoci to isté urobil už dávno i Západ (vel’a lekcií druhého čítania v liturgii hodín - breviári pochádza práve od východných cirkevných otcov). Autentická miestna karpatská tradícia je však stále len málo prebádanou a zživotnenou. Tieto pramene systematicky vedecky sprístupňuje aj SÚJS SAV. ${ }^{14}$ Ide napr. o Užhorodský rukopisný Pseudozonar, ${ }^{15}$ Štatúty Mukačev-

\footnotetext{
${ }^{12}$ Východné teologické dedičstvo je inšpiratívne aj pre protestantské prostredie. Pozri Svatoň, R.: Doteky křest’anského Východu v protestantské teologii 20. století. Schlink, Pelikan, Torrance, Mannermaa, Moltmann. Červený Kostelec: Pavel Mervart, 2018, 245 s.

${ }^{13}$ Porov. Taft, R. F.: Katolicizmus východného obradu. Jeho dedičstvo a poslanie. Košice - Bratislava: Centrum spirituality Východ-Západ Michala Lacka - Teologická fakulta Trnavskej univerzity, 2007, 48 s.

${ }^{14}$ Žeňuch, P.: Prameň ako východisko kultúrnej pamäti: Monumenta byzantino-slavica et latina Slovaciae. In Slavica Slovaca, 2020, roč. 55, č. 3, s. 482-493 a tiež Žeňuch, P.: Cyrilské písomníctvo na Slovensku v kontexte aktuálnych výskumov. In Žeňuch, P. a kol.: Pohl'ady do problematiky cyrilskej písomnej tradície na Slovensku. Bratislava: Slavistický ústav Jána Stanislava SAV - Slovenský komitét slavistov - VEDA, vydavatel'stvo SAV, 2019, s. 11-30.

15 Žeňuch, P. (red., ed.): Užhorodský rukopisný Pseudozonar. Pravidlá mníšskeho a svetského života z prelomu 16.-17. storočia. Ужгородский рукописный Псевдозонар. Правила монашеской и светской жизни рубежа XVI-XVII вв. Monumenta byzantino-slavica et latina Slovaciae V. Bratislava - Москва - София - Košice: Veda, vydavatel'stvo Slovenskej akadémie vied - Slavistický ústav Jána Stanislava SAV - Институт поссийской истории РАН - Кирило-
} 
ského gréckokatolíckeho biskupstva, ${ }^{16}$ Rukovät’ cirkevných dejín, ${ }^{17}$ Obraz mníšskeho života. ${ }^{18}$ Tie poukazujú na jednu a jedinú spirituálnu líniu, ktorá nebola Užhorodskou úniou ani prerušená ani zničená, ale pokračovala, zvel'ad'ovala sa. Dejiny svedčia o napredovaní, ked' sa obidve spoločenstvá, východné i západné, priblížili alebo dotkli ako tangenty. To však bolo možné len vtedy, ked' samé zvel'ad’ovali vlastné duchovné a kultúrne dedičstvo, ktorým potom obohatili toho druhého. Spoločné tangenty a prieniky záujmov latinskej a západnej cirkvi pod Karpatmi boli v konečnom dôsledku vždy vzájomne prospešné, viedli k intelektuálnemu, náboženskému a kultúrnemu obohateniu, k očiste historickej pamäte i revitalizácii morálnych a duchovných hodnôt.

\title{
Латинско-византийское сожительство под Карпатами как возможность ревитализации ценностей
}

\author{
Петер Зубко
}

\begin{abstract}
Латинская и византийская церкви сосуществуют в регионе под Карпатами уже несколько веков. Эта область прошла своим собственным путем исторического развития, в котором можно выделить несколько этапов. Самой важной вехой этого развития было создание греко-католической церкви в результате заключения Ужгородской унии в 1646 году. Как и везде на целом свете, под Карпатами тоже возникали разнообразные критические ситуации и напряженность во взаимоотношениях конфессиональных и этнических сообществ. В конечном итоге подобные напряженности оказались полезными для обеих сторон. Интерес к оппоненту и презентация собственной системы ценностей внесли свой вклад в духовную и культурную коммуникацию. В результате явной конкуренции каждое сообщество было вынуждено укреплять свое собственное самосознание и углублять историческую память. Однако при важнейших исторических событиях обе группы объединяли свои силы и выступали единым фронтом против внешних врагов церкви. Соприкосновение и пересечение интересов латинской и восточной церкви под Карпатами в конечном итоге всегда было выгодно обеим сторонам. В настоящей статье рассмотрен этот второстепенный аспект взаимоотношений между латинской и византийской конфессиональной средой в регионе под Карпатами.
\end{abstract}

методиевски научен център БАН - Slovenský komitét slavistov - Centrum spirituality Východ-Západ Michala Lacka Teologickej fakulty TU, 2018, 448 s.

${ }^{16}$ Zubko, P. - Žeňuch, P.: Diecézne štatúty Michala Manuela Olšavského z rokov 1752-1758. In: Slavica Slovaca, 2019, roč. 54, č. 3-4 (supplementum), s. 5-100.

${ }^{17}$ Žeňuch, P. - Zubko, P.: Michal Bradač - Rukovät' cirkevných dejín. Monumenta Byzantino-Slavica et Latina Slovaciae VIII. Bratislava: Veda - Slavistický ústav Jána Stanislava SAV, 2021, 464 s.

${ }^{18}$ Wilšinská, L.: Joannikij Juraj Bazilovič: Imago Vitae Monasticae / Obraz mníšskeho života: Štúdia a preklad. In: Slavica Slovaca, 2020, roč. 55, č. 4 (supplementum), s. 3-226. 